\title{
СИНДРОМ ГІПЕРОСМОЛЯРНОЇ ГІПОГІДРАТАЦІЇ В ЕКСПЕРИМЕНТІ: ОСОБЛИВОСТІ ПОРУШЕНЬ ВІТАЛЬНИХ ФУНКЦІЙ ЩУРІВ ПРИ РОЗЛАДАХ ГОМЕОСТАЗУ РІЗНОГО СТУПЕНЯ ТЯЖКОСТІ
}

\section{Синдром гіперосмолярної гіпогідратації в експерименті: особливості порушень вітальних функцій щурів при розладах гомеостазу різного ступеня тяжкостl \\ ю. В. Гнатів, М. М. Корда \\ Тернопільський національний медичний університет імені І. Я. Горбачевського МОЗ України}

Резюме. У нейрохірургічних хворих ураження гіпоталамо-гіпофрізарної ділянки у 30 \% випадків ускладнюється розвитком центрального нецукрового діабету, який проявляється грубими розладами водно-сольового балансу, що призводить до функціональних порушень і структурних ушкоджень органів і тканин, та може завершитися смертю. Моделювання в експерименті гіперосмолярної гіпогідратації, що розвивається при нецукровому діабеті, допомогло б сприяти вивченню біохімічних та патофрізіологічних процесів, які відбуваються при цьому.

Мета дослідження - змоделювати в експерименmі синдром гіперосмолярної гіпогідратації, дослідити особливості змін поведінки, фрізичного стану та біохімічних показників тварин залежно від рівня осмолярності плазми крові.

Матеріали і методи. В експерименті використали статевозрілих щурів - самок $(n=62)$ масою $(242,0 \pm 15,0)$ 2. Для моделювання гіперосмолярної гіпогідратації їм внутрішньочеревно вводили розчинн фруросеміду $\left(5,0\right.$ мг.к $\left.2^{-1}\right)$, та під наркозом із застосуванням натрію тіопенталу (50 мг мг.ке-1) внутрішньовенно - гіпертонічні (від 1,8 до 9 \%) розчини натрію хлориду (по 2,0 мл). Досліджували темп діурезу, шільність сечі, обчислювали осмотично-об'ємний індекс сечі та ступінь гіпогідратації організму, фрізичний стан і тривалість наркозу (коми), електроліти плазми крові $\left(\mathrm{Na}^{+}, \mathrm{K}^{+}\right)$, ї̈ осмолярність, а також летальність тварин залежно від ступеня тяжкості змодельованої гіперосмолярної гіпогідратації.

Результати. В експерименті на щурах змодельовано гіпертонічну (гіперосмолярну) гіпогідратацію різного ступеня тяжкості, яка виникає у хворих на центральний нецукровий діабет; відображено клініколабораторні особливості, які спостерігаються при цьому, та вивчено механізми організму, які задіяні на ї подолання.

Висновки. При втраті води експериментальними тваринами в об'ємі >5 \% від маси тіла тривалість
Syndrome of hyperosmolar hypohydration in the experiment: features of disorders of vital functions of rats with disorders of homeostasis of varying severity

Yu. V. Hnativ, M. M. Korda

I. Horbachevsky Ternopil National Medical University

e-mail: hnativuv@tdmu.edu.ua

Summary. In neurosurgical patients, hypothalamicpituitary lesions in $30 \%$ of cases are complicated by the development of central diabetes mellitus, which is manifested by severe disorders of water-salt balance, leading to functional disorders and structural damage to organs and tissues, and can be fatal. Modeling in the experiment of hyperosmolar hypohydration, which develops in diabetes insipidus, would help to study the biochemical and pathophysiological processes that occur.

The aim of the study - to simulate in the experiment the syndrome of hyperosmolar hypohydration, to investigate the peculiarities of changes in behavior, physical condition and biochemical parameters of animals depending on the level of osmolarity of blood plasma.

Materials and Methods. The experiment used adult female rats $(n=62)$ weighing $(242.0 \pm 15.0) \mathrm{g}$. To model hyperosmolar hypohydration, they were injected intraperitoneally with a solution of furosemide $\left(5.0 \mathrm{mg} \cdot \mathrm{kg}^{-1}\right)$, andunderanesthesiawith sodium thiopental (50 mg mg $\cdot \mathrm{kg}^{-1}$ ) intravenous - hypertonic (from 1.8 to $9 \%$ ) solutions of sodium chloride $(2.0 \mathrm{ml})$. The rate of diuresis, urine density, calculated osmotic-volume index of urine and the degree of hypohydration of the body, physical condition and duration of anesthesia (coma), blood plasma electrolytes $\left(\mathrm{Na}^{+}, \mathrm{K}^{+}\right)$, its osmolarity and mortality of animals depending on the severity of the simulated hyperosmolar hypohydration.

Results. The experiment on rats simulated hypertensive (hyperosmolar) hypohydration of varying severity, which occurs in patients with central diabetes mellitus; the clinical and laboratory features observed in this case are reflected, and the mechanisms of the organism involved in its overcoming are studied.

Conclusions. With the loss of water by experimental animals in the amount of $>5 \%$ of body weight, the duration of narcotic action of thiopental sodium (50 $\mathrm{mg} \cdot \mathrm{kg}^{-1}$ ) is prolonged more than 2 times. When intravenous
ISSN 2706-6282(print) ISSN 2706-6290(online)
Вісник медичних і біологічних досліджень Bulletin of Medical and Biological Research
$4(10), 2021$ 


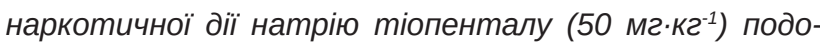
вжується у понад 2 рази. При внутрішньовенному введенні зневодненим (5,2 \% від маси тіла) щурам гіпертонічних розчинів розвивається гіперосмолярна кома, тривалість якої корелює із величиною осмолярності плазми. Потенційно небезпечним для життя щурів $\epsilon$ зростання натрію плазми крові понад 180 ммоль або їі осмолярності>360 мосм·л ${ }^{-1}$. Осмотично-об'ємний індекс сечі - ефрективний неінвазивний діагностичний критерій порушень водно-сольового обміну та ефективності його корекції в експериментальних тварин. У нормі в щурів цей показник становить 910,2士28,4, різко знижується (у понад 10 разів) при стимуляції діурезу салуретиками та може зростати до 5061,3ะ54,2 при нирковій компенсації гіперосмолярного синдрому.

Ключові слова: центральний нецукровий діабет; гіперосмолярна гіпогідратація; гомеостаз; осмотичнооб'ємний індекс сечі.

\section{ВСТУП}

У нейрохірургічних хворих ураження гіпоталамогіпофрізарної ділянки у 30 \% випадків ускладнюється розвитком центрального нецукрового діабету, який проявляється грубими розладами водно-сольового балансу, що призводить до фрункціональних порушень і структурних ушкоджень органів і тканин, та може завершитися смертю [1]. Моделювання в експерименті гіперосмолярної гіпогідратації, яка розвивається при нецукровому діабеті, допомогло б сприяти вивченню біохімічних та патофрізіологічних процесів, що відбуваються при цьому.

\section{МАТЕРІАЛИ I МЕТОДИ}

При проведенні досліджень дотримувались положень Європейської конвенції про захист хребетних тварин, що використовуються для дослідних та інших наукових цілях (Страсбург, 1986); Директиви Ради Європи 86/609/EEC (1986р.); Закону України № 3447 - IV «Про захист тварин від жорстокого поводження»; Загальних етичних принципів експериментів на тваринах, ухвалених Першим національним конгресом України 3 біоетики (2001р.).

Дослідження проведено на 62-х білих безпородних щурах-самках масою тіла $(242,0 \pm 15,0)$ г, які протягом періоду проведення експерименту, перебували у комі, не вживали їжу та не пили воду. Після зважування 58 щурам внутрішньочеревно вводили розчин фруросеміду із розрахунку 5,0 мг·кг-1 [2]. Для збирання сечі кожну тварину поміщали в окремий контейнер. Контрольну групу склали 4 тварини.

У наступні дві години спостерігали за поведінкою щурів, вимірювали темп діурезу (об'єм сечі, виділеної за годину) [3] з розрахунку на 100 г маси тіла. Вимірювали осмотичну щільність сечі ветеринарним рефрактометром, оцінюючи показник за шкалою «саt». administration of hypertonic solutions to dehydrated $(5.2 \%$ of body weight) hyperosmolar coma develops, the duration of which correlates with the value of plasma osmolarity. Potentially life-threatening in rats is an increase in blood plasma sodium above $180 \mathrm{mmol} \cdot \mathrm{l}^{-1}$ or its osmolarity $>360$ mosm $\cdot l^{-1}$. Osmotic volume index of urine is an effective non-invasive diagnostic criterion for disorders of watersalt metabolism and the effectiveness of its correction in experimental animals. Normally, in rats, this figure is (910.2 \pm 28.4$)$, decreases sharply (more than 10 times) when stimulating diuresis with saluretics and may increase to $(5061.3 \pm 54.2)$ with renal compensation of hyperosmolar syndrome.

Key words: central diabetes mellitus; hyperosmolar hypohydration; homeostasis; osmotic volume index of urine.

Обчислювали осмотично-об'ємний індекс сечі (ООІС) за фрормулою, яку ми розробили [4], модифрікувавши її для досліджень у дрібних тварин:

$$
\text { OOIC }=\frac{(\text { ЩС }-1000) \cdot 100}{3 \cdot \text { Угод }(\text { МТ: } 100)}
$$

де ООІС - осмотично-об'ємний індекс сечі, ЩС - щільність сечі,

V год - об'єм сечі, виділеної протягом години, МТ - маса тіла тварини.

Через 2 год щурів вводили у наркоз, застосовуючи розчин натрію тіопенталу (50 мг·к $\Gamma^{-1}$ внутрішньочеревно). Після засинання тваринам у бокову вену хвоста вводили по 2 мл розчину натрію хлориду різної концентрації (тваринам групи № $1-1,8 \%$, № $2-2,7 \%$, № $3-3,6 \%$, № $4-4,5 \%$, № 5 - 5,4 \%, № $6-6,3 \%$, № $7-7,2 \%$, № 8 - 8,3 \%, № $9-9 \%)$.

Досліджували поведінку щурів, забарвлення й тургор шкіри і видимої слизової оболонки, температуру тіла, частоту дихання, тривалість наркозу (коми), темп діурезу і щільність сечі, а також тривалість життя тварин. У крові вимірювали рівень гематокриту, концентрацію $\mathrm{Na}^{+}, \mathrm{K}^{+}$, осмолярність плазми.

\section{РЕЗУЛЬТАТИ Й ОБГОВОРЕННЯ}

Після введення фруросеміду протягом двох годин кожна із дослідних тварин виділяла по 12,0-13,0 мл сечі; із групи контролю - по 2,0-3,0 мл (табл. 1). При цьому осмотична щільність сечі у тварин дослідної групи була суттєво нижчою $(p<0,01)$, ніж у групі контролю. Це підтверджує дані щодо механізму дії салуретиків, які понижують здатність нирок концентрувати сечу [5]

Установили, що в нормі (у щурів групи контролю) OOIC (на 100 г маси) становить близько 910,0 (890-930). У тварин, яким застосовували сечогінний середник, цей індекс понижувався більше ніж у 10 разів. 


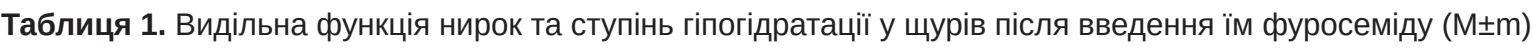

\begin{tabular}{|c|c|c|}
\hline \multirow{2}{*}{ Показник } & \multicolumn{2}{|r|}{ Група щурів } \\
\hline & інтактний контроль & після застосування фруросеміду \\
\hline Об'єм сечі, виділеної протягом 2 год, мл & $2,51 \pm 0,13$ & $12,6 \pm 0,18^{\star *}$ \\
\hline Темп діурезу, мл·100г-1. год-1 & $0,52 \pm 0,10$ & $2,63 \pm 0,15^{\star \star}$ \\
\hline Осмотична щільність сечі, г·л ${ }^{-1}$ & $1014,2 \pm 1,2$ & $1006,5 \pm 1,8^{\star \star}$ \\
\hline Осмотично-об'ємний індекс сечі & $910,2 \pm 28,4$ & $82,4 \pm 1,2^{\star *}$ \\
\hline Ступінь гіпогідратації організму щурів, \% (від маси тіла) & $1,0 \pm 0,04$ & $5,2 \pm 0,11^{\star *}$ \\
\hline
\end{tabular}

Примітка. * - p<0,05; ** - p<0,01 порівняно з показниками у тварин контрольної групи.

Розрахунок об'єму втраченої із сечею рідини відносно маси тіла дає змогу виставити ступінь гіпогідратації (у \%) [6]. У дослідних тварин через 2 год після введення фруросеміду маса тіла зменшувалася на $(5,2 \pm 0,11) \%$, разом 3 тим, як у тварин групи контролю - близько 1 \%. Згідно з класифрікацією [7], втрата води в об'ємі понад 5 \% від загальної маси тіла характеризується як гіпогідратація середнього ступеня тяжкості.

Отже, введений щурам внутрішньоплеврально фуросемід у дозі 5 мг·100г-1 через 2 год спричинював гіпогідратацію середнього ступеня тяжкості; відбувалося переважання виділення з організму води над солями. При цьому фізичний стан експериментальних тварин суттєво не змінювався. Частота дихання і температура тіла достовірно не відрізнялися від тварин групи контролю. Спостерігали активну мотиваційну поведінку у вигляді пошуку джерела води та незначну загальмованість реакцій на орізичні подразнення.

Під дією натрію тіопенталу тварини засинали: приймали бокове положення, у них відбувалося сповільнення частоти дихання та пригнічення реакцій на фрізичні подразнення. При цьому виявили значне продовження тривалості наркозу в тварин, яким вводили фруросемід (до 120-150 хв), на відміну від щурів контрольної групи, наркоз у яких тривав до 65 хв (табл. 2). Така особливість перебігу наркозу, на нашу думку, зумовлена поліурією, гіповолемією та гіпогідратацією, викликаною сечогінним середником.

Другий етап експерименту. Тваринам на тлі наркозу внутрішньовенно вводили по 2 мл гіпертонічних розчинів натрію хлориду різної концентрації. Виявили, що тривалість та глибина наркозу ще більш суттєво подовжувалися.

Даний френомен, імовірно, пояснюється трансформуванням у тварин наркотичного сну в стан гіперосмолярної коми, спричиненої дією концентрованих розчинів натрію хлориду на тлі гіпогідратації. Щури займали будь-яке, не притаманне їм положення: на спині, на животі, на боці; при їхньому перекладанні зовсім не чинили спротиву, не змінюючи положення тіла. Дихання ставало поверхневим, рідким (до 50-40 на хвилину), дещо пришвидшуючись після нанесення больових подразнень. У тварин, які у подальшому загинули, періодично виникали клонічні судоми. Температура тіла у них понижувалася до $36^{\circ} \mathrm{C}$, шкіра набувала ціанотичного відтінку, а тургор їі суттєво знижувався. Видима слизова оболонка була сухою, на

Таблиця 2. Тривалість наркозу (гіперосмолярної коми) та летальність щурів при введенні їм на тлі гіпогідратації

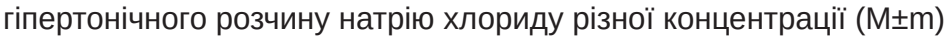

\begin{tabular}{|c|c|c|c|c|c|}
\hline \multirow{2}{*}{ Група щурів } & \multicolumn{2}{|c|}{$\begin{array}{c}\text { Характеристика введеного } \\
\text { розчину } \mathrm{NaCl} \\
\end{array}$} & \multicolumn{2}{|c|}{ Тварини, які залишилися живими } & \multirow{2}{*}{$\begin{array}{l}\text { Кількість загиб- } \\
\text { лих тварин, шт. }\end{array}$} \\
\hline & $\begin{array}{l}\text { концентра- } \\
\text { ція, \% }\end{array}$ & $\begin{array}{c}\text { осмолярність, } \\
\text { мосм } \cdot \pi^{-1}\end{array}$ & $\begin{array}{l}\text { кількість, } \\
\text { шт. }\end{array}$ & $\begin{array}{c}\text { тривалість наркозу (гіперос- } \\
\text { молярної коми), хв }\end{array}$ & \\
\hline Контрольна & - & - & 4 & $55-65$ & 0 \\
\hline Під дією фруросеміду & - & - & 4 & $120-150$ ** & 0 \\
\hline № 1 & 1,8 & 628 & 6 & $320,5 \pm 20,3^{\star \star}$ & 0 \\
\hline № 2 & 2,7 & 942 & 6 & $400,0 \pm 22,6^{\star \star}$ & 0 \\
\hline № 3 & 3,6 & 1256 & 6 & $486,2 \pm 31,5^{\star \star}$ & 0 \\
\hline № 4 & 4,5 & 1570 & 4 & $568,6 \pm 38,2^{\star \star}$ & 2 \\
\hline № 5 & 5,4 & 1884 & 4 & $606,4 \pm 35,0^{\star \star}$ & 2 \\
\hline № 6 & 6,3 & 2198 & 5 & $622,5 \pm 32,6$ *夫 & 1 \\
\hline № 7 & 7,4 & 2512 & 3 & $644,6 \pm 42,0$ ** & 3 \\
\hline № 8 & 8,3 & 2826 & 1 & 782,0 & 5 \\
\hline № 9 & 9,0 & 3140 & 0 & $460,0 \pm 60,2^{\star *}$ & 6 \\
\hline
\end{tabular}

Примітка. * - p<0,05; ** - p<0,01 порівняно з показниками у тварин контрольної групи.

ISSN 2706-6282(print)

ISSN 2706-6290(online)
4(10),2021 
ній чітко проявлялися повздовжні (на язику) та циркулярні (на губах, біля носа) складки.

У тварин, які вижили, тривалість коми становила від $(320,5 \pm 20,3)$ до 782,0 хв. При цім спостерігали пряму залежність між концентрацією введеного гіпертонічного розчину, тривалістю коми та числом загиблих тварин.

У щурів, які у подальшому загинули (19 тварин), відмічали глибоке пригнічення усіх рефлексів, аж до повної ареолексії; дихання у них ставало поверхневим, прогресувала гіпотермія, брадипное і судоми; смерть настала протягом 10-12 год. Необхідно відмітити, що перші випадки летальності зареєстровані у тій групі щурів, яким вводили гіпертонічні розчини натрію хлориду, починаючи із концентрації 4,5\% (загинули дві тварини). При введенні їм 9 \% розчину натрію хлориду гинули усі щури (табл. 3)

У тварин під дією фруросеміду суттєве зростання гематокриту ( $<<0,01)$ свідчило про гіпогідратацію. Недостовірне підвищення натрію та осмолярності плазми при цьому вказувало на її ізотонічний характер; при таких порушеннях вода втрачається в основному із позаклітинного сектора організму.

У тих же щурів, яким внутрішньовенно вводили гіпертонічні розчини натрію хлориду, фрормувався гіперосмолярний синдром. При цім чітко простежувалося зростання вмісту іонів натрію та підвищення осмолярності плазми, синхронне із концентрацією гіпертонічних розчинів, введених їм.

Таким чином, ізотонічна гіпогідратація, яка виникала у щурів під дією фруросеміду, після введення гіпертонічних розчинів натрію хлориду набувала характеру гіпертонічної (або гіперосмолярної). У міру підвищення осмолярності плазми крові в тварин усіх дослідних груп відбувалося переміщення води із клітинного сектора у позаклітинний в усе більшому об'ємі. Підтвердженням такої дисгідрії слугувало пониження гематокриту, синхронне - зростанню осмолярності плазми.

При зростанні осмолярності до показника 370 мосм $\int^{-1}$ (натрій при цьому становив >184 ммоль $л^{-1}$ - група № 4) загинули дві тварини, а при ще більш високому її рівні - 400 мосм·л ${ }^{-1}$ (натрій > 205 ммоль·л ${ }^{-1}-$ група № 9) гинули усі щури.

Результати, отримані під час експерименту, корелюють із даними, притаманними хворим на нецукровий діабет. Відмічено, що при зростанні осмолярності плазми крові на величину понад 30 мосм/л від верхньої границі норми спостерігається порушення діяльності ЦНС [5].

У плазмі крові експериментальних тварин на тлі зростання гіпернатріємії спостерігали дозо-залежне пониження концентрації іншого катіона - калію (від 5,1 ммоль $\cdot л^{-1}$ у тварин групи № 1 - до 3,9 ммоль л $^{-1}-$ у тварин групи № 9). Такі зміни, очевидно, зумовлені компенсаторними механізмами: завдяки виведенню калію із позаклітинного сектора відбувається якоюсь мірою зменшення вмісту осмотично активних часточок крові [8].

Однак на відміну від центрального нецукрового діабету, який зумовлений дефріцитом антидіуретичного гормону [1], в експериментальних тварин відбувалося активне включення його у регуляторні процеси. Нирки тварин навіть в умовах гіпогідратації продовжували продукувати сечу, виводячи із нею надмір солей. При цьому різко зростала осмотична щільність сечі (табл. 4).

Щури, тривалість коми у яких продовжувалася 8 год, протягом цього періоду продукували по $(5,2 \pm 1,2)$ мл сечі 3 урахуванням попередніх втрат води під дією фруросеміду, ступінь загальної гіпогідратації склав уже $(7,4 \pm 0,5)$ \% від маси тіла, що становить загрозу життю [9]. Однак навіть в умовах гіпогідратації відбувається стимуляція сечовиділен-

Таблиця 3. Зміни показників плазми крові щурів при моделюванні у них різних варіантів гіперосмолярної гіпогідратації $(\mathrm{M} \pm \mathrm{M})$

\begin{tabular}{|c|c|c|c|c|c|}
\hline \multirow[t]{2}{*}{ Група щурів } & \multirow{2}{*}{$\begin{array}{c}\text { Концентрація введе- } \\
\text { ного розчину } \mathrm{NaCl}, \\
\%\end{array}$} & \multirow{2}{*}{$\begin{array}{c}\text { Гематокрит, } \\
л^{-} \int^{-1}\end{array}$} & \multicolumn{2}{|c|}{$\begin{array}{c}\text { Електроліти плазми } \\
\text { крові, ммоль·л"-1 }\end{array}$} & \multirow{2}{*}{$\begin{array}{c}\text { Осмолярність } \\
\text { плазми, мосм·л-1 }\end{array}$} \\
\hline & & & $\mathrm{Na}^{+}$ & $\mathrm{K}^{+}$ & \\
\hline Контрольна & - & $0,50 \pm 0,03$ & $147,5 \pm 1,0$ & $5,2 \pm 0,4$ & $297,3,0 \pm 3,4$ \\
\hline $\begin{array}{l}\text { Під дією фруросе- } \\
\text { міду }\end{array}$ & - & $0,58 \pm 0,03^{\star \star}$ & $148,9 \pm 1,4$ & $5,1 \pm 0,3$ & $299,5 \pm 4,8$ \\
\hline № 1 & 1,8 & $0,56 \pm 0,03^{\star *}$ & $157,9 \pm 1,2^{\star *}$ & $5,1 \pm 0,4$ & $316,9 \pm 4,3^{\star \star}$ \\
\hline № 2 & 2,7 & $0,56 \pm 0,02^{* *}$ & $164,6 \pm 1,3^{\star \star}$ & $4,9 \pm 0,4$ & $329,8 \pm 4,8^{\star \star}$ \\
\hline № 3 & 3,6 & $0,55 \pm 0,02^{\star \star}$ & $178,8 \pm 1,4^{\star \star}$ & $4,8 \pm 0,3$ & $355,0 \pm 3,9 * \star$ \\
\hline № 4 & 4,5 & $0,55 \pm 0,03^{\star *}$ & $184,2 \pm 1,4^{\star \star}$ & $4,7 \pm 0,5$ & $366,1 \pm 5,0^{\star \star}$ \\
\hline № 5 & 5,4 & $0,54 \pm 0,02^{\star \star}$ & $189,9 \pm 1,3^{\star \star}$ & $4,3 \pm 0,4$ & $376,0 \pm 4,9 * \star$ \\
\hline № 6 & 6,3 & $0,54 \pm 0,03^{\text {** }}$ & $194,5 \pm 2,0^{\star *}$ & $4,2 \pm 0,3^{\star}$ & $384,6 \pm 4,2^{\star \star}$ \\
\hline № 7 & 7,4 & $0,54 \pm 0,04^{\star \star}$ & $198,6 \pm 1,9$ ** & $4,1 \pm 0,4^{\star}$ & $392,2 \pm 4,0$ ** \\
\hline № 8 & 8,3 & $0,54 \pm 0,04$ ** & $202,0 \pm 2,1^{\star \star}$ & $4,1 \pm 0,3^{\star}$ & $399,3 \pm 4,3^{\star \star}$ \\
\hline № 9 & 9,0 & $0,53 \pm 0,05^{\star \star}$ & $206,4 \pm 2,0$ ** & $3,9 \pm 0,3^{*}$ & $406,9 \pm 3,8^{\star \star}$ \\
\hline
\end{tabular}

Примітка. * - p<0,05; ** - p<0,01 порівняно з тваринами контрольної групи. 


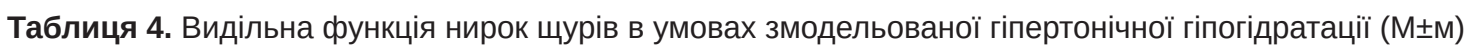

\begin{tabular}{|c|c|c|c|c|c|}
\hline \multirow{2}{*}{ Показник } & \multirow{2}{*}{$\begin{array}{c}\text { У контрольній } \\
\text { групі, } \\
\text { через } 8 \text { год }\end{array}$} & \multicolumn{4}{|c|}{ У тварин дослідної групи № 4 час із моменту настання коми } \\
\hline & & 2 год & 4 год & 6 год & 8 год \\
\hline Об'єм виділеної сечі, мл & $7,8 \pm 0,4$ & $1,6 \pm 0,2$ & $1,3 \pm 0,3$ & $1,2 \pm 0,2$ & $1,1 \pm 0,1$ \\
\hline Темп діурезу, мл·100г'-1.год ${ }^{-1}$ & $0,40 \pm 0,17$ & $0,33 \pm 0,12$ & $0,27 \pm 0,13$ & $0,25 \pm 0,13$ & $0,23 \pm 0,15$ \\
\hline Осмотична щільність сечі, г·л ${ }^{-1}$ & $1018,0 \pm 0,3$ & $1039,4 \pm 3,6^{\star \star}$ & $1041,0 \pm 2,5^{\star \star}$ & $1038,1 \pm 1,8^{\star \star}$ & $1034,3 \pm 1,1^{\star \star}$ \\
\hline Осмотично-об'ємний індекс сечі & $1500,2 \pm 28,8$ & $3939,4 \pm 42,5^{\star \star}$ & $5061,3 \pm 54,2^{\star *}$ & $5066,7 \pm 56,7^{\star \star}$ & $4971,0 \pm 60,3^{\star \star}$ \\
\hline $\begin{array}{l}\text { Ступінь гіпогідратації організму } \\
\text { щурів, \% }\end{array}$ & $4,2 \pm 0,1$ & $5,8 \pm 0,2^{\star \star}$ & $6,4 \pm 0,2^{\star \star}$ & $6,9 \pm 0,3$ ** & $7,4 \pm 0,5^{\star \star}$ \\
\hline
\end{tabular}

Примітка. * - p<0,05; **- p<0,01 порівняно з показниками у тварин контрольної групи.

ня - один із найпотужніших механізмів, задіяних організмом для виведення надміру солей та нормалізації осмолярності плазми крові [10].

Про компенсаторні спроможності організму щурів свідчить осмотично-об'ємний індекс сечі, який був вищим понад норму в 5 разів.

Щури, які залишалися живими, поступово, протягом 6-8 год виходили із коми та ставали усе більш активними; процеси життєдіяльності нормалізовувалися, а після вживання води та їжі їхній фрізичний стан повністю відновлювався.

\section{ВИСНОВКИ}

1. В експерименті на щурах змодельовано гіпертонічну (гіперосмолярну) гіпогідратацію різного ступеня тяжкості, яка виникає у хворих на центральний нецукровий діабет; відображено клініко-лабораторні особливості, які спостерігаються при цьому, та вивчено регуляторні механізми, що задіяні, на її подолання.

\section{СПИСОК ЛІТЕРАТУРИ}

1. Garrahy A. Management of endocrine disease: Neuroendocrine surveillance and management of neurosurgical patients / A. Garrahy, M. Sherlock, C. J. Thompson // Eur. J. Endocrinol. - 2017. - Vol. 176 (5). - P. 217-223.

2. Маркіна А. Ю. Фармакологічне дослідження естерів N-[(2-оксоіндолініліден-3)-2-оксіацетил]-амінокислот як потенційних діуретичних засобів : дис. канд. фрарм. наук / А. Ю. Маркіна. - Харків, 2019. - 194 с.

3. Недашківський С. М. Інфузійна терапія в періопераційному періоді / С. М. Недашківський, О. А. Галушко // Гострі та невідкладні стани у практиці лікаря. - 2016. T. 5 (26). - C. 42-45.

4. Hnativ Yu. V. Osmotically volumetric urine index in early recognition and evaluation of the central diabetes insipidus correction efficiency / Yu. V. Hnativ // Journal of Education, Health and Sport. - 2021. - Vol. 11 (11). - P. 58-66.

5. Савин И. А. Водно-электролитные нарушения В нейрореанимации / И. А. Савин, А. С. Горячев. - М., 2015. - С. 331.
2. При втраті води експериментальними тваринами в об'ємі >5 \% від маси тіла тривалість наркотичної дії натрію тіопенталу (50 мг·кг-1) подовжується у понад 2 рази.

3. При внутрішньовенному введенні зневодненим (5,2 \% від маси тіла) щурам гіпертонічних розчинів розвивається гіперосмолярна кома, тривалість якої корелює із величиною осмолярності плазми. Потенційно небезпечним для життя тварин є зростання натрію плазми крові понад 180 ммоль-л-1 або іiї осмолярності >360 мосм-л-1.

4. Осмотично-об'ємний індекс сечі - ефективний неінвазивний діагностичний критерій порушень водно-сольового обміну та ефрективності його корекції в експериментальних тварин. У нормі в щурів цей показник становить 910,2 28,4 , різко знижується (у понад 10 разів) при стимуляції діурезу салуретиками та може зростати до 5061,3ะ54,2 при нирковій компенсації гіперосмолярного синдрому.

6. Недашківський С. М. Дегідратаційний синдром: класифікація, клініка, інфузійна терапія / С. М. Недашківський, О. А. Голубовська, О. А. Галушко // Раціональна фрармакотерапія. - 2018. - Т. 1 (46). - С. 23-27.

7. Хартиг В. Современная инфузионная терапия / В. Хартинг. - М. : Медицина, 1982. - 496 с.

8. Dietary sodium and health: more than just blood pressure / W. B. Farquhar, D. G. Edwards, C. T. Jurkovitz, W. S. Weintraub // J. Am. Coll. Cardiol. - 2015. - Vol. 65 (10). - P. 1042.

9. Мима М. Горн, Урсула И. Хейтц, Памела Л. Сверинген. Водно-электролитный и кислотно-основной баланс / Мима М. Горн, Урсула И. Хейтц, Памела Л. Сверингер ; пер.с англ. - СПб. ; М. : «Невский Диалект» ; «Издательство БИНОМ», 2000. - 320 с.

10. Функциональный почечный резерв: фризиология, патосризиология и диагностика / А. И. Гоженко, Д. Д. Иванов, В. М. Никитенко, В. М. Сирман. - К., 2019. - 151 с.
$4(10), 2021$ 


\section{REFERENCES}

1 Garrahy A, Sherlock M, Thompson CJ. Management of endocrine disease: Neuroendocrine surveillance and management of neurosurgical patients. Eur $\mathrm{J}$ Endocrinol. 2017;176(5): 217-23.

2. Markina AYu. Pharmacological study of esters of $\mathrm{N}$ - [(2-oxoindolinylidene-3) -2-oxyacetyl] -amino acids as potential diuretics. PhD thesis. Ukrainian.

3. Nedashkivskyi SM, Halushko OA. [Infusion therapy in the perioperative period]. Hostri ta nevid stan u prakt lik. 2016;5(26): 42-5. Ukrainian.

4. Hnativ YuV. Osmotically volumetric urine index in early recognition and evaluation of the central diabetes insipidus correction efficiency. Journal of Education, Health and Sport. 2021;11(11): 58-66.

5. Savin IA, Goryachev AS. Water-electrolyte disturbances in neuroresuscitation. [Водно-электролитные нарушения в нейрореанимации] Moscow; 2015. Russian.

6. Nedashkivskyi SM, Holubovska OA, Halushko OA.
[Dehydration syndrome: classification, clinical practice, infusion therapy]. Ratsional farmakoter. 2018;1(46): 23-7. Ukrainian.

7. Hartig V. Modern infusion therapy. [Современная инфрузионная терапия] Moscow: Meditsina; 1982. Russian.

8. Farquhar WB, Edwards DG, Jurkovitz CT, Weintraub WS. Dietary sodium and health: more than just blood pressure. J Am Coll Cardiol. 2015;65(10): 1042.

9. Mima M Gorn, Ursula I Heyts, Pamela L. Sveringen. Water-electrolyte and acid-base balance. [Водноэлектролитный и кислотно-основной баланс]. St.Petersburg-Moscow: Nevskiy Dialekt Izdatelstvo BINOM; 2000. Russian.

10. Gozhenko Al, Ivanov DD, Nikitenko VM, Sirman VM. Functional renal reserve: physiology, pathophysiology and diagnostics [Функциональный почечный резерв: фризиология, патофизиология и диагностика]. Kyiv; 2019. Russian. 